\title{
PERSPEKTIF HISTORIS KESADARAN KEBANGSAAN DAN KEMERDEKAAN INDONESIA BERDIMENSI KEBUDAYAAN
}

\author{
Bambang Purwanto \\ Departemen Sejarah, Fakultas Ilmu Budaya, UGM \\ purwantougm@yahoo.co.uk
}

\begin{abstract}
The idea of Indonesia as an independent nation began to be threatened, when groups of political elites and certain communities began to imagine not to be part of the big house of Indonesia. This situation made all parties aware of how importance historiography and national collective memory in shaping, understanding and maintaining national consciousness and Indonesian independence as an integrative and holistic way of thinking. In contrast to the studies that have existed so far which emphasize the political dimension, this paper places national awareness and Indonesian independence in the sphere of its cultural dimension. When national consciousness and independence is understood in the cultural dimension, the Proclamation of 17 August 1945 together with Pancasila could no longer be referred to as mere political products, but as a national culture.

Abstrak: $\quad$ Cita-cita Indonesia sebagai kesatuan bangsa yang merdeka mulai terancam, ketika sekelompok elite politik dan masyarakat tertentu mulai membayangkan untuk tidak lagi menjadi bagian dari rumah besar Indonesia. Keadaan ini menyadarkan semua pihak betapa pentingnya kesadaran historis dan memori kolektif bangsa dalam membentuk, memahami, dan memelihara kesadaran kebangsaan dan kemerdekaan Indonesia sebagai cara berpikir yang integratif dan menyeluruh. Berbeda dengan kajian yang ada selama ini yang hanya menekankan pada dimensi politik, tulisan ini menempatkan kesadaran kebangsaan dan kemerdekaan indonesia dalam ruang dimensi kebudayaannya. Ketika kesadaran kebangsaan dan kemerdekaan dipahami dalam dimensi kebudayaan, maka Proklamasi 17 Agustus 1945 bersama-sama Pancasila tidak lagi dapat disebut sebagai produk politik semata, melainkan sebagai kebudayaan bangsa.

Kata Kunci: Indonesia, kebangsaan, kemerdekaan, kebudayaan, historiografi
\end{abstract}

\section{PENDAHULUAN}

Ketika Proklamasi kemerdekaan Indonesia akan memasuki usia ke-74 pada tahun ini (2019), berbagai permasalahan kebangsaan ternyata masih terus melanda negeri ini. Biarpun pada satu sisi kesadaran kebangsaan Indonesia pada kelompok-kelompok tertentu termasuk generasi mudanya terus menguat, di sisi yang lain keraguan terhadap keberlanjutan Indonesia di masa depan juga terus bermunculan.

Dalam kategori politik Indonesia misalnya, baik dalam kehidupan sehari-hari maupun secara akademis, dikotomi antara kelompok nasionalis dengan non-nasionalis masih tetap mengemuka. Masing-masing kelompok dianggap merepresentasi kadar tingkat kesadaran kebangsaan, dimana loyalitas terhadap Indonesia diukur dari berbagai simbol yang dihadirkan oleh masing-masing kelompok. Sikap saling menuduh antara satu kelompok dengan kelompok yang lain sebagai tidak nasionalis, kurang nasionalis, nasionalis buta dan sebagainya terus hidup hampir dalam seluruh ruang kehidupan Indonesia sampai saat ini sebagai kecurigaan struktural dan sekaligus kultural.

Merujukberbagai referensi yang ada, euforia desentralisasi dan otonomi daerah dalam penyelenggaraan pemerintahan yang merupakan bagian dari proses demokratisasi yang telah berlangsung beberapa dekade terakhir ini, ditengarai menjadi salah satu sebab yang mendorong semakin menguatnya identitas kedaerahan beserta ikatan primordial lainnya, yang melupakan isensi keindonesian sebagai sebuah ikatan bersama negara bangsa.
Sementara itu intervensi puritanisasi dan radikalisasi keyakinan dan ideologi yang beririsan dengan proses globalisasi serta arus besar transnasional, sampai batas tertentu juga diyakini sebagai salah satu sumber yang menciptakan keadaan berseberangan secara terus menerus dengan ide-ide dasar keindonesian yang inklusif dan mengutamakan keberagaman. Dampak yang hampir serupa juga dapat dilihat lebih jauh pada kekeruhan situasi yang merupakan akibat dari adanya interpretasi sepihak dan liberal terhadap wujud pengejewantahan atas nilai-nilai kebangsaan, dan adanya dominasi negara yang kuat dalam memahami nasionalisme dan kemerdekaan. Dalam konteks yang terakhir itu, nasionalisme hanya dipahami secara politis, dengan mengesampingkan realitas sosio-kulturalnya, dimana publik seharusnya mampu menterjemahkan kesadaran kebangsaan dalam kehidupan sehari-hari mereka tanpa harus merujuk pada difinisi nasionalisme yang dikemukakan oleh rezim yang sedang berkuasa.

Oleh karena itu, berbagai kelompok politik dan masyarakat mulai membayangkan tentang tidak akan ada lagi masa depan jika terus bergabung bersama dalam label besar bernama Indonesia. Berpisah dari Indonesia atau kembali ke masa lalu sebagai unit-unit yang terpisah-pisah seperti sebelum munculnya kesadaran kebangsaan Indonesia, dianggap sebagai pilihan yang terbaik. Hal itu berkaitan erat dengan adanya kenyataan bahwa bagi sebagian orang, Indonesia harus dijalankan dengan prinsip-prinsip keyakinan atau ideologi eksklusif tertentu secara politik. Indonesia dan ideologi dasarnya Pancasila, seakan-akan hanya menjadi 
milik satu kelompok tertentu saja. Padahal ketika mereka bersumpah atas nama kedua-duanya, semua itu tidak lebih dari sekedar gincu dan topeng pemanis rupa, bukan ketulusan sebagai warganegara.

Ketika para elite politik tertentu menyatakan bahwa mereka melakukan sesuatu demi bangsa, negara, atau rakyat, pada dasarnya segala tindakan mereka tidak lebih merupakan perwujudan dari proses penghancuran sistematis dan struktural terhadap kesadaran kebangsaan Indonesia yang bermuara pada Proklamasi kemerdekaan 17 Agustus 1945. Atau dengan kata lain, sebagian elite politik itu hidup dalam kemunafikan berkelanjutan, yang mengancam eksistenti kebangsaan Indonesia. Akibatnya bagi sebagian orang, Indonesia dibayangkan akan segera menjadi sejarah. Barang antik yang menarik dan bernilai tinggi, tetapi tidak lagi memiliki ruh kehidupan. Nilai yang tinggi dari Indonesia tidak terletak pada keberhasilannya untuk tetap terus hidup, melainkan pada eksotisme yang muncul dari sebuah kegagalan yang membawa serta berbagai potensi yang sangat luar biasa dalam kematiannya.

Bayang-bayang yang pesimis itu berbeda dengan pendapat Robert E. Elson dalam buku tentang kebangkitan nasional Indonesia yang diterbitkan satu dekade yang lalu. Menurut salah seorang sejarawan Australia terkemuka yang banyak menulis tentang sejarah Indonesia ini, "ide tentang Indonesia yang telah berlangsung selama satu abad atau lebih itu tidak menunjukkan ada tanda-tanda surut dalam kekuatannya yang menggairahkan". Lebih lanjut ia mengatakan bahwa, kegairahan untuk terus hidup itu didukung oleh banyak orang Indonesia yang benar-benar menyadari bahwa, "negara bangsa ini benar-benar negerinya, dan mereka sendirilah yang harus tetap menjaganya" (Elson, 2008). Indonesia mampu beradaptasi dengan modernitas, sehingga mewarisi dan sekaligus mewariskan nilai-nilai universal yang mencakup kesetaraan berazaskan hukum, keadilan sosial, tanggung jawab demokratik, dan kemanusiaan yang beradab.

Latar belakang di atas memacu pertanyaan sederhana, dalam hal apakah dan sejauhmanakah sejarah sebagai historiografi dan ingatan sejarah bersama dapat digunakan sebagai salah satu unsur pokok dalam membentuk dan merawat kesadaran kebangsaan Indonesia di tengah berbagai perubahan yang terus terjadi dan mengancam eksistensinya? Tulisan ini beranjak dari dasar berpikir bahwa sebagai sebuah bangsa dan negara, Indonesia tentu saja memiliki sejarahnya sendiri, yang merupakan representasi dari masa lalunya yang tidak bisa dipisahkan dari masa kini demi keberlanjutannya di masa depan. Sementara itu pada saat yang sama, keberadaan Indonesia merupakan bagian yang tidak terpisahkan dari "arus sejarah" dunia (Abdullah \& Lapian, 2012), mengutip judul "buku induk" sejarah Indonesia terbaru yang diterbitkan beberapa tahun lalu. Merujuk pada cara berpikir Kuntowijoyo, maka tulisan ini bertujuan untuk menghadirkan historiografi yang dapat berfungsi sebagai kritik sosial (Kuntowijoyo, 2000), ketika konstruksi dan pemaknaan terhadap kenyataan masa lalu bukan merupakan antikuarian.

Oleh karena itu, penelusuran secara menyeluruh sejarah proses terbentuknya Indonesia dan bagaimana ide tentang keindonesiaan itu terus berlanjut selama ini sebagai

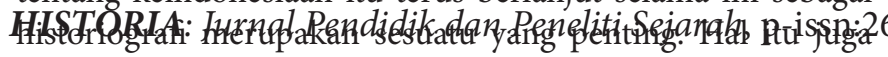

diyakini akan mampu memahami dan sekaligus mengapresiasi betapa pentingnya arti dari keberadaan Indonesia itu. Keberadaan Indonesia diasumsikan tidak hanya penting bagi mereka yang hidup di negeri yang pada paroh kedua abad ke19 pernah disebut oleh Eduard Douwes Dekker atau Multatuli - pengarang buku Max Havelaar - sebagai "Insulinde yang cemerlang" ini (Multatuli, 1991). Nama "Insulinde" kemudian juga digunakan oleh E.F.E. Douwes Dekker, salah satu tokoh pendiri Indische Partij yang juga memiliki hubungan kekerabatan dengan Multatuli, bagi nama organisasi baru yang didirikannya pada tahun 1913, setelah Pemerintah Hindia Belanda melarang Indische Partij dan mengasingkan para pendirinya.

Keberadaan Indonesia yang berkelanjutan juga penting bagi sejarah dunia dan umat manusia secara keseluruhan. Indonesia merupakan salah satu representasi historis dan sekaligus simbolik dari dunia baru, yang lahir dan tumbuh melampaui batas-batas dunia lama yang eksploitatif, diskriminatif, dan segregatif. Keberadaan Indonesia tidak hanya sekedar representasi dari nasionalisme industrialis sebagaimana dipahami dalam perspektif modernisme, melainkan produk dari keadaban yang menentang industrialisasi dan modernisasi itu sendiri sebagai salah satu keunikan dalam sejarah umat manusia. Dalam konteks inilah, tulisan ini akan menempatkan kesadaran kebangsaan Indonesia dalam dimensi kebudayaan, bukan politik sebagaimana dilakukan dalam berbagai studi yang ada selama ini.

\section{Dimensi Kultural Nasionalisme}

Tulisan ini mengacu pada dasar berpikir bahwa pembentukan Indonesia pada dasarnya merupakan salah satu simpul utama dalam sejarah peradaban umat manusia. Terdapat perbedaan pendapat tentang sejarah kata Indonesia untuk merujuk pada negeri dan bangsa Indonesia. Menurut Presiden Sukarno, nama Indonesia merupakan kata majemuk Yunani Indusnesos atau kepulauan yang terletak dekat dengan India, yang merujuk pendapat seorang etnolog Jerman bernama Jordan. Sementara pendapat lain mengatakan bahwa, kata itu digunakan pertama kali oleh Adolf Bastian pada akhir abad ke-19. Akan tetapi menurut Moh. Hatta Wakil Presiden Indonesia pertama yang mendasari pendapatnya pada Kreemer, kata Indonesia digunakan pertama kali oleh etnolog Inggris J.R. Logan pada tulisannya yang terbit pada tahun 1850, dan sebelum itu sarjana Inggris lain bernama G.W. Earl telah menggunakan kata Indu-nesian. Menurut sejarawan Jepang Akira Nagazumi yang telah melakukan penelitian tentang pergerakan kebangsaan Indonesia, pendapat Moh. Hatta dianggap lebih kuat daripada Sukarno (Nagazumi, 1976).

Sementara itu beberapa tahun sebelum Indonesia memproklamasikan kemerdekaan, Paul K. Benedict menggunakan terminologi Indonesia untuk merujuk pada asal usul rumpun bahasa di Asia Tenggara yang berasal dari Cina selatan, Tonkin utara, dan Hainan dalam artikel ilmiah yang ditulisnya (Benedict: 1942). Adanya berbagai pendapat dan kompleksitas dari asal usul dan penggunaan kata Indonesia itu juga dapat dilihat lebih jauh pada tulisan G.C. Molewijk

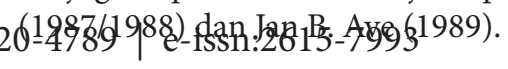


Selama ini, pemahaman tentang nasionalisme sangat didominasi oleh difinisi umum tentang nasionalisme sebagai "gerakan ideologis untuk mencapai dan memelihara pemerintahan sendiri dan kemerdekaan atas nama kelompok dimana sebagian dari anggotanya menyadari potensi sebagai sebuah bangsa" sebagaimana dinyatakan oleh Anthony D. Smith (Smith, 1983). Akibatnya, dimensi politik sangat mendominasi semua pembicaraan tentang nasionalisme sebagian sebuah kesadaran kebangsaan yang tidak terpisah dengan upaya untuk memiliki negara dan pemerintahan sendiri. Padahal Smith sendiri sangat menyadari, bangsa pada dasarnya terbentuk dari sekelompok orang yang merasa memiliki kebudayaan bersama yang berbeda dari yang lain. Mereka merasa berhak atas status warganegara, "yang tinggal bersama dalam satu teritorial dan dipersatukan oleh satu sistem ekonomi, serta membangun solidaritas karena pengalaman bersama sebagai sebuah kebudayaan" (Smith, 1983).

Dominasi dimensi politik yang besar itu tentu saja menjadi salah satu sebab mengapa nasionalisme jarang sekali dipahami sebagai sebuah kenyataan kebudayaan. Kegamangan ini berkaitan erat dengan kenyataan bahwa dalam perspektif modernisme kebudayaan lebih sering dipahami sebagai antikuarian yang merujuk kepada masa lalu. Padahal sebagaimana dinyatakan oleh D.V. Kumar, baik secara sosiologis maupun ideologis pada dasarnya nasionalisme merupakan sesuatu yang baru. Nasionalisme dan bangsa "bukan versi baru yang dicari-cari dari sesuatu yang sudah ada sebelumnya”. Lebih lanjut Kumar menyatakaan bahwa pada prinsipnya nasionalisme dan bangsa merupakan "sesuatu hal yang baru secara keseluruhan karena keadaan yang membentuknya adalah baru" (Kumar, 2010).

Pada titik inilah dapat dijelaskan mengapa setiap pembicaraan tentang kesadaran kebangsaan cenderung mengingkari dimensi kebudayaannya, karena sifat otonomi dan kedaulatan yang merupakan unsur penting dalam nasionalisme hanya dipahami sebagai kenyataan politik. Dalam konteks sejarah nasionalisme Indonesia, cara berpikir politis ini menjadi salah satu faktor penyebab dari kegagalan memahami Ki Hadjar Dewantara dalam realitas sejarah Indonesia. Narasi sejarah menyatakan bahwa Ia hanya berpolitik ketika aktif dalam kegiatan Budi Utomo, Sarekat Islam, dan Indische Partij sebagai Soewardi Soerjaningrat, sedangkan sebagai Ki Hadjar Dewantara, ia dilabelkan sebagai aktivis pendidikan dan kebudayaan. Padahal dalam kenyataannya, Ki Hadjar Dewantara atau Soewardi Soerjaningrat tidak pernah berhenti berpolitik melalui kegiatan pendidikan dan kebudayaan sebagai sebuah strategi melalui Taman Siswa, tempat dimana ide-ide kebangsaannya diinkubasi dan diimplementasikan (Purwanto, 2017).

Mengacu pada pendapat lain dari D.V. Kumar, pada prinsipnya setiap aktivitas memobilisasi massa atau merekayasa tradisi sebagaimana yang terjadi dalam proses historis dari kesadaran kebangsaan, pada prinsipnya keberadaannya bukan sebagai sesuatu yang baru secara keseluruhan. Lebih lanjut Kumar menyatakan bahwa hal tersebut pada dasarnya "tetap harus tergantung pada apa yang sudah pernah ada sebelumnya" (Kumar, 2010). Pada titik inilah sebenarnya nasionalisme dapat dikatakan sebagai perwujudan integratif antara masa

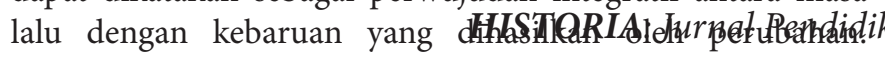

Ketika hal ini dikaitkan dengan pendapat Ernest Gellner yang menyatakan bahwa nasionalisme adalah "a general imposition of a high culture on society" (Gellner, 1983), maka tidak ada alasan lagi untuk memungkiri adanya dimensi kebudayaan dalam proses terbentuk dan berkembangnya kesadaran kebangsaan. Lebih jauh menurut Gellner, secara kronologis nasionalisme sebagai cara berpikir bersama merupakan unsur yang membentuk satu bangsa tertentu, sebuah konsep politik kolektif yang tidak ada sebelumnya, bukan sebaliknya. Biarpun Gellner dikenal sebagai pemikir yang berpihak pada perspektif modernisme dalam memahami nasionalisme, D.V. Kumar percaya bahwa pengembangan lebih lanjut dari kerangka berpikir dasar yang dikemukakan Gellner mampu memberi arah baru yang membuka ruang bagi dimensi lain dalam mamahami nasionalisme (Kumar, 2010), tentu saja termasuk didalamnya adalah dimensi kebudayaan.

Dalam konteks ini, kebudayaan tidak dipahami sebagai nilai-nilai luhur yang hidup di masa lalu, melainkan sebagai strategi berpikir dan intelektual transformatif masyarakat pendukungnya yang merupakan respon terhadap berbagai perubahan nilai yang terus terjadi. Hal ini mengantar kita untuk merujuk pada kerangka berpikir yang dikemukakan oleh Umar Kayam dan Kuntowijoyo. Menurut Umar Kayam, transformasi budaya merupakan sebuah keniscayaan dalam masyarakat yang terus berubah (Kayam, 1989). Sementara itu merujuk pada kerangka besar pemikiran Kuntowijoyo, transformasi itu seharusnya tidak membuat sebuah bangsa terasing dari dirinya sendiri (Kuntowijoyo, 2000). Sampai pada tataran ini, kekinian dan masa depan yang cemerlang hanya akan terbentuk ketika sebuah bangsa tidak melepaskan masa lalunya sebagai sebuah keutuhan kebudayaan. Hidup dengan masa lalu adalah identitas, sementara itu perubahan adalah keniscayaan dalam kehidupan masa kini dan masa depan yang visioner, sebagai rentetan yaang tidak terpisahkan untuk tetap hidup dengan identitas yang terbentuk dari dalam dirinya sendiri.

Dalam kenyataannya, walaupun disadari betul bahwa suatu bangsa memang tidak akan pernah bisa menjadi bangsa yang lain sampai kapanpun, dalam banyak kasus sering terjadi bahwa pada saat yang sama sebuah bangsa punya kecenderungan untuk berusaha keras atau bahkan berpurapura menjadi sesuatu yang sama dengan yang lain. Bahkan tindakan menyamakan dirinya dengan yang lain diposisikan sebagai perwujudan dari nilai lebih yang dimilikinya. Padahal baik secara teoretik maupun pengalaman historis, ketika kecanggungan, kepura-puraan, dan ketidakpastiaan kultural menjadi nilai dasar yang dibawa secara terus menerus dari waktu ke waktu terutama bagi bangsa yang muncul dari puing-puing kolonialisme dan imperialisme, jangan berharap kemajuan, kesejahteraan, dan keunggulaan yang berkelanjutan akan tercapai, sebagaimana dicita-citakan oleh kesadaran kebangsaan dan kemerdekaan yang menyertainya.

Keterasingan baik dari dirinya sendiri maupun di tengahtengah bangsa lain akan terus menerus menghantui, sehingga bangsa tersebut terjebak secara struktural dalam gaya tarik titik nol ke sumbu negatif dan membuat dirinya hidup tanpa kebudayaannya sendiri. Dalam perspektif modernisme, kecenderungan itu hanya mampu memberi ruang kemajuan

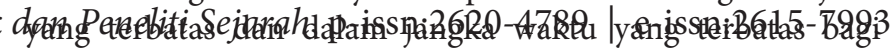


bangsa tersebut, untuk kemudian berbalik untuk selalu memulai lagi dari titik awal sebagaimana telah dilakukan berkali-kali sebelumnya. Kemajuan bukan merupakan kosa kata yang akrab dalam sejarahnya, sebaliknya kata krisis memenuhi proses sejarah dari bangsa tersebut.

\section{Membangun dan Merawat Kesadaran Kebangsaan serta Kemerdekaan Indonesia}

Di dalam narasi besar sejarah sebagaimana digambarkan dalam buku yang disunting oleh Jennifer Lindsay bersama Maya H.T. Liem, Indonesia digambarkan sebagai ahli waris budaya dunia (Lindsay \& Liem (ed), 2011). Pernyataan itu menyisakan pesan bahwa Indonesia bukan merupakan induk dalam proses pembentukan kebudayaan dunia, melainkan ruang kosong yang diisi oleh berbagai budaya yang ada di dunia. Pernyataan itu tentu saja tidak dapat disalahkan begitu saja, mengingat berbagai budaya besar yang hidup di Indonesia baik pada masa lalu maupun sampai masa kini memang merupakan produk impor yang menemukan tanah yang subur di negeri ini. Biarpun begitu jika dilihat dari sisi yang lain dalam proses pembentukan dan perkembangan kesadaran kebangsaannya, Indonesia sebenarnya mewariskan sesuatu bagi budaya dunia.

Eksistensi Indonesia yang dicita-citakan para pendiri bangsa ini, pada dasarnya tidak hanya menyangkut terciptanya entitas politik merdeka yang muncul dari sebuah koloni yang pernah disebut sebagai Achter-Indie atau Hindia Belakang ini. Indonesia juga harus dipahami sebagai sebuah peradaban baru, yang merupakan antitesa kultural dari imperialisme dan kolonialisme yang diskriminatif dan kapitalisme yang eksploitatif seiring dengan berkembangnya prinsip-prinsip kemanusiaan dan nasionalisme demokratis yang melanda dunia paling tidak sejak akhir abad ke-19 dan awal abad ke-20. Ide-ide itu secara eksplisit menempatkan kemerdekaan dan penghargaan atas harkat serta martabat umat manusia sebagai sesuatu yang utama, tanpa melepaskan dirinya dari nilai-nilai keseimbangan spiritualitas ketuhanan. Hal yang terakhir ini merupakan keunikan yang terbentuk dalam sejarah Indonesia, yang merupakan salah satu dari representasi dunia Timur yang tetap menempatkan spiritualitas ditengah-tengah sekularitas yang terus berkembang bersamaan dengan modernisasi yang dipahami sebagai pembaratan.

Indonesia bukan sekedar komunitas politik yang dibayangkan karena mereka tidak mungkin saling mengenal satu dengan yang lain seperti dikatakan oleh Benedict Anderson (Anderson, 2006), melainkan materialisasi kongkrit dari proses sejarah yang menyertakan berbagai unsur dalam pembentukannya. Secara historiografis, Indonesia harus dipahami sebagai sebuah kenyataan budaya, bukan sebuah kesemuan yang diciptakan oleh kolonialisme. Keberadaan kolonialisme dalam proses pembentukan Indonesia memang merupakan sebuah keniscayaan, akan tetapi Indonesia seharusnya tidak dipahami sebagai kolonialisme yang berganti topeng wajah namun dengan keutuhan tubuh dan pikiran yang masih sama. Indonesia merupakan sebuah produk berbudaya, bukan hanya produk politik sebagaimana dipahami selama ini baik oleh para akademisi maupun dalam memori kolektif bangsa. HISTORI
Keberadaan Indonesia berkaitan erat dengan keputusan yang dibuatnya sendiri, perwujudan dari cara berpikir kolektif sebagai paradigma kebudayaan untuk menghasilkan apa yang dapat disebut sebagai budaya menjadi bangsa. Penetapan satu bahasa selain satu tanah air dan satu bangsa pada Sumpah Pemuda 28 Oktober 1928, merupakan salah satu contoh menarik untuk dapat menempatkan Indonesia sebagai salah satu pusat budaya dunia, biarpun disadari betul masih terdapat beberapa hal yang perlu diperdebatkan lebih jauh. Ketika bahasa Melayu diadopsi menjadi bahasa Indonesia, jelas hal itu bukan keputusan politis seperti selama ini dipahami, melainkan keputusan kultural. Baik memori kolektif bangsa maupun analisa akademik selama ini, selalu menempatkan peristiwa ini sebagai wujud dari kerelaan atau pengorbanan politis orang Jawa yang berjumlah lebih banyak atas mereka yang berjumlah lebih sedikit. Padahal dalam kenyataannya sebagaimana dinyatakan oleh Imran T. Abdullah, selama beratus tahun sebelum kesadaran kebangsaan Indonesia terbentuk, bahasa Melayu telah menjadi lingua franca. Bahasa Melayu tidak hanya sebagai bahasa yang berlaku secara umum di seantero kepulauan Indonesia untuk perdagangan, melainkan juga bahasa dalam perkembangan intelektual, keagamaan, dan bahasa diplomasi (Abdullah, 2012).

Hal itu salah satunya dapat dilihat pada berbagai perjanjian yang ditandatangani antara bangsa Barat dengan para elite politik lokal, yang sejak awal selalu memiliki versi bahasa Melayunya. Ketika Islam berkembang menjadi agama dominan, bahasa juga Melayu menempati posisi yang paling penting sebagai medium komunikasi sepanjang proses sejarahnya. Bahkan di paro kedua abad ke-18 pada masa VOC, penduduk Pulau Rote di Nusa Tenggara Timur yang telah memeluk agama Nasrani, menyelenggarakan sendiri sekolahsekolah berbahasa Melayu (Ricklefs, 2001), yang merupakan bagian dari usaha penduduk lokal melakukan mobilitas sosial dan keluar dari praktek perbudakan yang sangat membebani kehidupan masyarakat sehari-hari.

Sementara itu pada konteks yang lain, berakhirnya kekuasaan negara kolonial Hindia Belanda pada bulan Maret 1942, tidak serta merta menghasilkan Indonesia sebagai sebuah entitas yang mandiri. Jepang hadir sebagai penguasa kolonial baru menggantikan Belanda. Bangsa Indonesia memutuskan sendiri untuk merdeka pada 17 Agustus 1945, biarpun tanpa harus menunggu sampai benar-benar siap untuk menjadi bangsa yang merdeka, sebagaimana disampaikan oleh Sukarno pada pidatonya dalam sidang BPUPK 1 Juni 1945 (Departemen Penerangan RI: 1964).

Peristiwa itu tidak dapat dipisahkan dari perubahan paradigmatik yang menunjukkan kepercayaan diri yang besar sebagai kebudayaan dari proses menjadi bangsa. Oleh karena itu Indonesia tidak hanya sekedar sebagai identitas kolektif secara politik, melainkan juga identitas kolektif secara kultural. Indonesia sebagai sebuah bangsa menegasikan Belanda dan juga Jepang sebagai sebuah ikatan etnisitas yang berhak atas sebuah teritori. Indonesia yang didalam konteks kolonialisme dan imperialisme diposisikan sebagai representasi dari kawula, melalui nasionalisme bertransformasi menjadi warganegara, sementara Belanda dan Jepang sejak itu dikategorikan sebagai asing. 
Semua proses itu kemudian secara historiografis menjadikan penulisan sejarah Indonesia tidak mengenal konsep dekolonisasi, sebuah konsep yang akan meluluhlantakkan tidak hanya secara politik melainkan juga secara kultural makna dari Proklamasi kemerdekaan Indonesia 17 Agustus 1945. Oleh karena itu konflik politik dan militer dengan Belanda antara 1945-1949 bukan merupakan bagian dari dekolonisasi. Di dalam narasi besar sejarah bangsa Indonesia, periode itu dikenal sebagai masa revolusi atau masa perang kemerdekaan Indonesia (Abdullah, 1997). Peristiwa yang melibatkan Indonesia dan Belanda itu merupakan konflik antara dua entitas setara, biarpun hal itu memang tidak bisa dipisahkan dari masa lalu panjang sejarah kolonialisme dan imperialisme Barat khususnya Belanda di wilayah ini. Indonesia menentukan dirinya sendiri untuk menjadi sebuah bangsa yang merdeka, dan hak atas kemerdekaan itu tidak ditentukan oleh proses dekolonisasi. Menempatkan konsep dekolonisasi ke dalam peristiwa sepanjang masa itu secara historiografis bukan sekedar mendelegitimasi pembentukan negara Republik Indonesia secara politis, namun yang lebih penting adalah secara kultural akan menjadikan hak atas kemerdekaan ditentukan oleh Belanda bukan oleh bangsa Indonesia sendiri.

Oleh karena itu, Indonesia harus diposisikan bukan sebagai Belanda atau Jepang yang pernah menjajahnya. Sementara itu Indonesia juga bukan Barat, Arab, India, atau pun Cina, yang memiliki pengaruh penting dalam proses sejarah dan kekiniannya. Indonesia adalah Indonesia, yang dalam pembentukannya merupakan hasil interaksi berbagai unsur internal dan eksternal yang berpusat pada kesadaran akan kemerdekaan dari kolonialisme, imperialisme, dan kapitalisme eksploitatif sebagai sebuah bangsa dan negara dalam ruang perkembangan peradaban umat manusia. Berbeda dari negara bangsa yang lain seperti Singapura misalnya, bangsa Indonesia lahir lebih dahulu, dan baru kemudian lahir Indonesia sebagai negara. Merujuk pada teks Proklamasi 17 Agustus 1945, Sukarno dan Mohammad Hatta atas nama bangsa Indonesia memproklamasikan kemerdekaan Indonesia, bukan negara Indonesia yang melakukannya.

Dalam perspektif sejarah, Indonesia sebagai sebuah entitas kebangsaan seperti yang kita kenal sekarang ini merupakan hal yang baru. Sesuatu yang muncul paling cepat pada akhir abad ke-19 dan awal abad ke-20 (Kartodirdjo, 2005), ketika muncul dan berkembang kesadaran akan perlunya identitas baru di kalangan mereka yang terjajah oleh rezim kolonial Belanda di wilayah yang mulai disebut Sukarno sebagai Nusantara pada sekitar dekade kedua abad ke-20. Nama Nusantara juga digunakan oleh seorang sejarawan Belanda B.H.M. Vlekke untuk bukunya tentang sejarah Indonesia yang terbit sebelum Indonesia merdeka (Vlekke, 2008). Menurut sejarawan Jepang Akira Nagazumi yang juga mendasari pendapatnya dari kajian-kajian yang pernah dilakukan oleh sejarawan Belanda G.J. Resink, ide nama Nusantara yang digunakan Vlekke didapatkannya dari Ki Hajar Dewantara. Akan tetapi para pendiri bangsa yang bukan berasal dari Jawa tidak menyukai kata Nusantara, karena menurut C.C. Berg kata itu bermakna "dunia luar" atau "pulau-pulau lain" yang dilihat dari Pulau Jawa.
Salah satu pembahasan terkini sekitar Nusantara ini dapat dilihat pada tulisan Hans Dieter-Evers yang diterbitkan beberapa tahun lalu (Dieter-Evers, 2016). Sebelum itu, berbagai kelompok suku dan bahkan bangsa yang tinggal di wilayah dari Sabang sampai Marauke ini, hidup terpisah-pisah baik secara sosio kultural maupun politik, sampai akhirnya mereka dipersatukan dalam sebuah ikatan Pax-Neerlandica di bawah kekuasaan kolonial Belanda (Kahin: 1955). Hal itu sekaligus mengisyaratkan bahwa Sriwijaya, Majapahit, Mataram, Makassar, Aceh, Minangkabau, Palembang, Melayu, Ternate, atau Tidore beserta entitas politik dan sosio kultural lainnya yang ada di seantero Nusantara ini tidak dapat begitu saja diidentikkan sama dengan Indonesia, namun tidak bisa dipisahkan juga.

Dalam konteks penulisan sejarah Indonesia, kompleksitas di atas memunculkan pertanyaan sederhana, apakah secara kultural dapat dikatakan bahwa kesadaran kebangsaan Indonesia merupakan kebangkitan kembali kekuatan nilai-nilai yang ada sebelum kolonialisme membangun dominasinya? Pertanyaan ini muncul sebagai reaksi kritis terhadap memori sosial bangsa yang selama ini selalu melihat bangsa Indonesia sebagai penjelmaan kembali dari "suatu bangsa besar, yang sejarahnya gilang gemilang dimasa dahulu” (Hatta: 1953). Lebih jauh Mohammad Hatta menyatakan, "karena penjajahan Belanda yang lebih dari 300 tahun lamanya, kita lupa akan kebangsaan kita, sehingga kita lupa akan kebudayaan kita yang begitu masjhur dimasa yang jauh silam" (Hatta: 1953). Oleh karena itu, kemunculan kesadaran kebangsaan Indonesia pada masa kolonial, menurut Mohammad Hatta merupakan perwujudan dari perasaan "rindu akan kebesaran bangsa kita dimasa yang sudah silam”. Sebuah bangsa "yang kuat bertindak, kuat mengembara menyebarkan kebudayaan kemana-mana" dengan menggunakan perahu "dari sepulau kesepulau didudukinya seluruh Nusantara ini, dan dengan itu didirikannya Tanah Air Indonesia bagi kita” (Hatta, 1953).

Hal itu berarti, pernyataan di atas seolah-olah menyiratkan bahwa jauh sebelum pengaruh Barat, khususnya kolonialisme dan imperialisme Barat merambah wilayah ini, bangsa Indonesia telah terbentuk. Secara historis seharusnya tidak ada kosa kata bangsa Jawa, bangsa Aceh, bangsa Bugis, bangsa Makassar, bangsa Melayu dan bangsa-bangsa lain untuk mengacu pada masyarakat atau kebudayaan yang hidup di ruang geografis yang dikenal sebagai Indonesia saat ini, kecuali bangsa dan kebudayaan Indonesia itu sendiri. Pernyataan seperti "engkau masing-masing bukan orang Banjar, bukan orang Samarinda, bukan orang Dayak, bukan orang Pontianak" dan "engkau tak lain, melainkan orang Indonesia, orang Indonesia semata" (Hatta: 1953), seakan akan tidak hanya berlaku pada konteks waktu ketika Mohammad Hatta menyampaikannya pada tahun 1945. Pernyataan itu seakan-akan dapat digunakan untuk menggambarkan kenyataan jauh sebelum kolonialisme berkuasa di wilayah ini. Padahal dalam konteks ilmu sejarah, semua hal di atas itu dapat dengan mudah dikaitkan dengan kekacauan orientasi ruang dan waktu atas sebuah realitas sejarah, anakronisme.

Biarpun begitu, tentu saja pernyataan di atas tidak dapat dijelaskan tanpa memahami konteks ketika hal itu disampaikan. Menempatkan Majapahit atau Aceh ke dalam dan Peneliti Sejarah, p-issn:2620-4789 | e-issn:2615-7993 
sejarah Indonesia sebagai contoh, sebenarnya hanya dapat dilakukan ketika keduanya dipahami sebagai bagian dari proses panjang transformasi yang berlangsung dalam sebuah ruang geo-politik dan kultural yang sama dan kemudian bernama Indonesia, namun bukan berarti keduanya identik sama dengan Indonesia. Singkat kata, Indonesia pada dasarnya merupakan hasil dari proses kreatif baik dalam arti politik maupun sosial budaya, yang berhasil mempersatukan berbagai elemen yang berbeda ke dalam satu identitas baru pada abad ke-20. Kesadaran itu sekaligus sebagai antitesa terhadap imperialisme, kolonialisme, dan kapitalisme yang direpresentasi oleh rezim kolonial. Kesadaran itu muncul dalam rangka membangun sebuah negara bangsa yang merdeka, yang berdasarkan kesepakatan bersama kemudian disebut Indonesia.

Ketika Mohammad Hatta menyatakan adanya eksistensi Indonesia di masa lalu jauh sebelum kehadiran kekuasaan kolonial dan sebelum kata itu ditemukan seperti yang telah digambarkan di atas, ia pada dasarnya bukan ingin mengatakan bahwa Majapahit atau Aceh sama dengan Indonesia. Mohammad Hatta melainkan sedang membangun sebuah strategi kebudayaan untuk memposisikan Indonesia dalam konteks sejarah peradaban dunia, ketika harus berhadapan dengan kekuasaan kolonial. Mohammad Hatta tidak bermaksud menulis sejarah, melainkan berpolitik untuk mensejajarkan diri atau bahkan lebih tinggi dari colonizer, dengan menggunakan kebudayaan sebagai media. Oleh karena itu, fakta-fakta sejarah yang dihadirkan Mohammad Hatta itu harus ditempatkan dalam konteks makna bukan substantif dari peristiwa itu sendiri. Sesuatu yang sering luput dalam pemahaman historis yang ada selama ini.

Bagi para sejarawan, pernyataan-pernyataan di atas tentu saja tetap menghadirkan banyak teka teki yang harus dijawab dan dijelaskan, terutama jika dikaitkan dengan keberadaan kesadaran kebangsaan Indonesia. Mengikuti cara berpikir Umar Kayam (Kayam, 1989) tentang transformasi budaya dan sejarawan Taufik Abdullah tentang terbentuknya kebudayaan nasional (Abdullah, 2001), pada dasarnya kesadaran kebangsaan Indonesia merupakan produk dari transformasi budaya yang terjadi berkali-kali dalam ruang yang sama, yang bermuara pada terbentuknya kemapanan kultural baru yang disebut Indonesia. Indonesia bukan Majapahit dan juga bukan Melayu, akan tetapi secara historis keberadaan Indonesia tidak dapat dipisahkan dari eksistensi Majapahit dan Melayu. Begitu juga dengan Barat. Indonesia memang bukan Barat, tetapi menghilangkan Barat dari eksistensi kesadaran kebangsaan Indonesia berarti menafikan kenyataan sejarah itu sendiri.

Memang sangat sulit untuk memungkiri bahwa terminal terdekat dari awal keberadaan Indonesia memang harus dicari di dalam sejarah kolonialisme terhadap wilayah yang pernah disebut sebagai Nederlandsch Indie atau Hindia Belanda ini, bukan di konteks yang lain atau masa yang lain. Akan tetapi hal itu bukan berarti bahwa Indonesia hanya bermuatan unsur kolonial, karena elemen-elemen terpisah yang kemudian dipersatukan menjadi Indonesia itu membawa serta identitas dan sejarah masing-masing untuk menjadi bagian yang tidak terpisahkan dengan identitas baru yang bernama Indonesia itu. Walaupun kata Nederlandsch Indie sudah dipakai sejak HISTORIA: Jurnal Pendidik dan Peneliti Sejarah, p-issn:2 abad ke-19, namun baru pada dekade kedua abad ke-20 nama itu mencakup seluruh wilayah yang sekarang disebut Indonesia.

Masa lalu dari semua elemen yang tercakup ke dalam identitas Indonesia itu secara otomatis menjadi masa lalu Indonesia juga. Salah satu hal yang dapat dijadikan contoh adalah, unsur-unsur yang ada di dalam identitas kolonial juga merupakan bagian yang tidak dapat dipisahkan dari identitas keindonesiaan. Menurut berbagai referensi yang ada, penggunaan identitas Indonesia sebagai wujud dari kesadaran politik serta kultural baru itu pertama kali berkembang di kalangan mahasiswa Indonesia di Belanda lewat pembentukan Indonesisch Verbond van Studeerenden (IVS) atau Serikat Mahasiswa-mahasiswa Indonesia Timur pada sekitar tahun 1916 atau 1917, sebuah organisasi yang menghimpun berbagai kelompok mahasiswa yang berasal dari koloni Belanda yang juga disebut Hindia Timur. Keberadaan organisasi ini tidak dapat dipisahkan dengan De Vrije Gedachte, organisasi yang dibentuk sebelumnya oleh Ki Hadjar Dewantara atau Soewardi Soerjaningrat, Ratu Langie, Yap dan Laboor dan Indische Vereeniging (IV) yang didirikan pada 1908. Sebagai salah satu anggota yang cukup dominan di dalam Indonesisch Verbond van Studeerenden yang ditandai oleh pengadopsian majalah IV bernama Hindia Poetra sebagai majalah resmi IVS, Indische Vereeniging terinspirasi untuk menggunakan nama Indonesische Vereeniging atau Perhimpunan Indonesia untuk nama barunya tidak lama setelah IVS dibubarkan pada tahun 1922, sementara itu majalah Hindia Poetra berubah menjadi Indonesia Merdeka pada tahun 1924 (Ingleson: 1993).

Elemen Barat atau pembaratan yang merupakan salah satu dasar utama dari kolonialisme merupakan salah satu unsur yang tidak bisa dihilangkan begitu saja dari identitas Indonesia. Baik atau buruk dan suka atau tidak suka, unsur Barat yang diwarisi dari kolonialisme itu merupakan sebuah kenyataan sejarah dari masa lalu Indonesia yang terus hidup di masa kini dan masa depan, seperti juga elemen-elemen pembentuk Indonesia lainnya.

Terlalu banyak unsur-unsur Barat baik secara sengaja maupun tidak disengaja telah bertransformasi seakan akan menjadi identitas asli Indonesia, yang dapat dijadikan sebagai contoh klasik dari kehadiran Barat di dalam entitas dan identitas Indonesia. Fakta-fakta sejarah yang berkaitan dengan arsitektur masjid raya di Banda Aceh dan perkembangan pendidikan Taman Siswa serta Muhammadiyah yang telah dianggap sebagai representasi keaslian simbolik baik dari kelokalan maupun keindonesiaan sebagai contoh, dalam kenyataannya memiliki hubungan genealogis yang kuat dengan tradisi yang berasal dari Barat. Oleh karena itu seperti telah disebutkan di atas, tidak berlebihan jika dikatakan bahwa menghilangkan unsur Barat dari Indonesia baik karena ketidaksetujuan atas hegemoni dan dominasi Barat saat ini maupun kolonialisme dan imperialisme di masa lalu, sama saja dengan memungkiri proses sejarah terbentuknya Indonesia itu sendiri.

Mengikuti cara berpikir beberapa ahli baik dari dalam maupun luar negeri, pada dasarnya selain Barat maka Indonesia modern juga mewarisi unsur-unsur Islam bersama-sama dengan kristalisasi unsur-unsur utama yang 620-4789 | e-issn:2615-7993 
telah berkembang sebelumnya dan melekat pada berbagai kelompok yang ikut serta dalam proses sejarah terbentuknya identitas baru bernama Indonesia. Pada konteks yang lain dan sampai batas-batas tertentu, penerimaan yang sama harus juga diberlakukan pada unsur-unsur Cina, India dan bahkan Jepang dalam identitas kekinian Indonesia karena proses sejarah yang telah berlangsung. Keberadaan unsur-unsur yang beragam itulah yang kemudian menjadi inspirasi atau dasar berpikir bagi para pendiri bangsa ini untuk menjadikan Pancasila sebagai dasar negara Indonesia yang merdeka, sebuah ideologi yang sejak awal ditempatkan sebagai sesuatu yang jauh dari eksklusivisme. Selain itu jangan dilupakan juga bahwa pada masa lalu, pendudukan yang tinggal di wilayah yang kemudian disebut dengan Indonesia ini telah secara bersama-sama dengan penduduk di wilayah sekitarnya membentuk sebuah identitas bersama yang dapat disebut sebagai "budaya asia tenggara”. Sebagaimana dinyatakan oleh Adrian Vickers, cerita Panji merupakan salah satu kontribusi besar Indonesia dalam ranah kebudayaan masyarakat yang hidup di sebagaian besar wilayah Asia Tenggara baik di kontinen maupun kepulauan (Vickers, 2009).

Salah satu konsekuensi yang harus diterima dari cara berpikir seperti di atas, kesadaran kebangsaan Indonesia pada dasarnya harus dikaitkan dengan keberagaman sebagai salah satu nilai dasarnya. Keberadaan Indische Partij, Perhimpunan Indonesia, dan Taman Siswa merupakan salah satu bentuk representasi dari kesadaran inklusif itu di masa lampau. Walaupun Muhammadiyah sebagai contoh, lebih sering dilihat sebagai representasi homogenitas karena ciri keislaman yang dimilikinya, dalam kenyataannya organisasi yang didirikan oleh Ahmad Dahlan ini merupakan bentukan baru yang tumbuh dan berkembang juga sebagai produk dari persilangan budaya di dalam keberagaman, yang melibatkan antara lain Islam, Jawa, modernitas Barat, dan Minangkabau. Oleh karena itu mengikuti kerangka berpikir Eddie Lembong (Rukmana \& Lembong, 2015), dapat disimpulkan bahwa Muhammadiyah pada dasarnya merupakan salah satu produk penyerbukan silang antarbudaya dalam proses kemodernan yang terjadi dalam masyarakat Indonesia pada masa kolonial Belanda di akhir abad ke-19 dan awal abad ke-20 (Purwanto, 2012).

Kemurnian nilai bukan menjadi isyu penting dalam kesadaran kebangsaan Indonesia. Adanya interindependensi menurut Soedjatmoko, menempatkan tuntutan atas kemurnian nilai menjadi tidak relevan (Soedjatmoko, 2001). Oleh karena itu dibutuhkan sebuah cara pandang yang historis, sehingga dapat memahami dan mewujudkan kesadaran kebangsaan itu sebagai tindakan-tindakan kongkrit. Mengikuti cara berpikir ini, maka kesadaran kebangsaan Indonesia harus "sadar akan kelampauan, [kita] bebas dalam kekinian dan bertanggung jawab untuk turut menentukan keakanan". Nasionalisme yang berakar kuat pada masa lalu, yang memiliki kesadaran visioner sebagai sebuah tanggung jawab untuk turut serta dalam proses sejarah menentukan sendiri arah masa depan, demi kemajuan dan kesejahteraan masyarakat pendukungnya. Nasionalisme tidak lagi sekedar sebuah tujuan politik, melainkan sebuah kebudayaan yang membangun nilai-nilai peradaban umat manusia. Hal ini sejalan dengan pendapat Ki
Hadjar Dewantara, dimana pendidikan pada dasarnya bukan bertujuan untuk meningkatkan status sosial dan kemampuan ekonomis anak bangsa, melainkan sebuah proses yang tidak terpisahkan dari peningkatan kebudayaan bangsa (Nayono et al., 1994).

Secara historis, salah satu bentuk lain yang menunjukkan kearifan dan kecerdasan budaya dari kesadaran kebangsaan Indonesia itu adalah Pancasila. Berbeda dengan pendapat selama ini yang cenderung melihat Pancasila hanya sebagai ideologi politik yang cenderung indoktrinatif, maka cara berpikir ini memposisikan Pancasila lebih sebagai kebudayaan nasional yang dibangun di atas fondasi kesepakatan bersama dari berbagai keberagaman yang ada di Indonesia. Atau dengan kata lain mengikuti cara berpikir Umar Kayam, Pancasila merupakan bagian yang tidak terpisahkan dari hasil transformasi budaya yang terjadi dalam masyarakat Indonesia. Pancasila pada dasarnya merupakan salah satu wujud dari "kearifan lokal bangsa". Pancasila adalah representasi dari kebudayaan bangsa Indonesia, yang tercipta seiring dengan kesadaran kebangsaan baru bernama Indonesia. Oleh karena itu, selalu berpikir dan bertindak dalam kerangka keberagaman merupakan representasi dari kearifan lokal Indonesia (Purwanto: 2013).

Pancasila merupakan perwujudan filosofis dari kesadaran kebangsaan Indonesia, yang berkembang pesat sepanjang paroh pertama abad ke-20. Sementara itu Proklamasi Kemerdekaan 17 Agustus 1945 merupakan perwujudan politis, dan Undangundang Dasar 1945 sebagai perwujudan konstitusional dari sejarah nasionalisme Indonesia itu. Walaupun akar keberadaan Pancasila dapat dirujuk jauh ke belakang pada masa prakolonial untuk nama misalnya, pada dasarnya kristalisasi nilai yang kemudian diadopsi menjadi muatan dalam Pancasila merupakan hasil dari pengalaman para pendiri bangsa Indonesia ketika berhadapan dengan kolonialisme, baik Belanda dan kemudian Jepang (Purwanto, 2013). Sila demi sila di dalam Pancasila merupakan pengejawantahan dari sifat keidonesiaan yang seharusnya dimiliki baik oleh negara maupun warganegaranya, yang berujung pada tujuan paling realistik dan manusiawi dari sebuah kemerdekaan, yaitu keadilan sosial bagi seluruh rakyat Indonesia. Keadilan sosial hanya bisa tercapai, jika rakyat Indonesia berdaulat dalam kemerdekaan, berpegang teguh pada persatuan berdasarkan nilai-nilai kemanusiaan dan musyawarah, tanpa melupakan eksistensi ketuhanan.

\section{SIMPULAN}

Terdapat pertanyaan sederhana yang harus dijawab dan dijelaskan pada bagian akhir tulisan ini, mengapa Proklamasi 17 Agustus 1945 tidak dijadikan sebagai salah satu pilar dari empat pilar kebangsaan Indonesia yang menjadi salah satu produk unggulan MPR sejak Reformasi? Padahal jika dipahami baik secara historis maupun simbolik, eksistensi kebangsaan Indonesia bermuara pada kemerdekaan. Maka dalam konteks ini Proklamasi yang disampaikan oleh Sukarno dan Mohammad Hatta atas nama bangsa Indonesia pada tanggal 17 Agustus 1945 adalah puncak dari tonggak sejarah bangsa dan simbol dari kemerdekaan itu. 
Dalam konteks kemerdekaan yang merupakan satu kesatuan dengan kesadaran kebangsaan Indonesia, Proklamasi kemerdekaan 17 Agustus 1945 memiliki arti yang sangat berbeda dengan 27 Desember 1949 sebagai "penyerahan kedaulatan/pengakuan kedaulatan” atau 17 Agustus 1950 yang menandai berakhirnya Republik Indonesia Serikat, sehingga akhirnya menempatkan Republik Indonesia sebagai satusatunya representasi formal dari keindonesiaan. Di dalam buku-buku sejarah selama ini dikatakan bahwa Yogyakarta menjadi ibukota Republik Indonesia dari Januari 1946 sampai dengan Desember 1949. Dalam kenyataannya, eksistensi Yogyakarta sebagai ibukota Republik Indonesia adalah sampai dengan Agustus 1950, karena eksistensi Jakarta dari Desember 1949 sampai dengan Agustus 1950 bukan merupakan ibukota Republik Indonesia melainkan Republik Indonesia Serikat, karena pada masa yang sama di Yogyakarta masih berdiri Republik Indonesia dibawah pimpinan Pemangku Presiden Assaat. Secara historis simbolik, Yogyakarta bersama-sama Sumatera Barat dan Aceh merupakan representasi utama dari pendukung Proklamasi kemerdekaan 17 Agustus 1945. Oleh karena itu meniadakan Proklamasi 17 Agustus 1945 dari pilar kebangsaan berarti meniadakan fondasi dan sekaligus roh atas kebangsaan Indonesia yang diusungnya. Meniadakan Proklamasi 17 Agustus 1945 dari pilar kebangsaan juga akan menjebak kita pada Indonesia dalam arti yang lain, bukan Indonesia yang asalnya lahir dari ibu pertiwi ketika berhadapan dengan kolonialisme dan imperialisme sebagai sebuah gerakan kebudayaan.

Pengabaian Proklamasi 17 Agustus 1945 dari pilar kebangsaan Indonesia pada dasarnya akan menghasilkan Indonesia yang jauh dari apa yang biasa disebut sebagai "jiwa atau semangat 45 ". Semangat yang merupakan kesadaran akan kemerdekaan diri sebagai bangsa dalam satu kesatuan keindonesiaan. Semangat 45 bukan semangat berjuang dalam peperangan, seperti yang banyak dipahami selama ini dan telah menjadi memori sosial bangsa. Semangat 45 tidak berdimensi politik apalagi militer, melainkan semangat kebudayaan dalam berbangsa. Mengingat kebudayaan merupakan semangat yang sangat diperlukan untuk membangun rasa tanggung jawab, agar dapat ikut serta menentukan sendiri masa depan bangsa dalam proses sejarahnya.

Sejarah umat manusia dan sejarah Indonesia sendiri telah mengajarkan, pemahaman sejarah bangsa yang utuh akan memberi inspirasi untuk menempatkan generasi muda saat ini dan masa depan tetap menjadi bagian terpenting bagi terbentuknya kegemilangan sebuah bangsa. Semua itu hanya akan tercapai di masa kini dan masa depan, jika semua warganegara tidak mengkhianati cita-cita yang mendasari terbentuknya kesadaran kebangsaan dan kemerdekaan Indonesia di masa lalu. Ketika kesadaran kebangsaan dan kemerdekaan dipahami dalam dimensi kebudayaan, Proklamasi 17 Agustus 1945 bersama-sama Pancasila tidak lagi dapat disebut sebagai produk politik semata, melainkan sebagai gerakaan kebudayaan dari proses pembentukan kesadaran kebangsaan dan kemerdekaan Indonesia. Dalam konteks yang terakhir inilah, historiografi dan memori kolektif bangsa memiliki fungsi penting secara kultural dalam membentuk, memahami, dan memelihara kesadaran kebangsaan dan kemerdekaan Indonesia sepanjang proses sejarahnya.

Oleh karena itu, memiliki cara pandang sejarah yang melihat kedepan dan bukan antikuarian merupakan salah satu kunci untuk dapat membangun kebudayaan dan mentalitas bangsa berdasarkan pengalaman sejarahnya sendiri. Bangsa Indonesia saat ini tidak hidup di masa lalu, tetapi juga tidak dapat melepaskan diri dari jejak masa lalunya. Keberhasilan menempatkan diri dengan tepat pada masa kininya berdasarkan pemahaman akan masa lalunya akan berbuah tanggung jawab atas masa depan bangsa, cita-cita yang harus terus dimiliki bangsa Indonesia agar dapat tetap bertahan di masa depan dalam kemerdekaan yang berkelanjutan.

\section{REFERENSI}

Abdullah, I. T. (2012). "Bahasa Melayu: Lingua Franca Islam”, Azyumardi Azra \& Jajat Burhanudin (ed.), Indonesia Dalam Arus Sejarah 3. Kedatangan dan Peradaban Islam. Jakarta: Ichtiar Baru van Hoeve, hlm. 232-251.

Abdullah, T., (2001). Nasionalisme \& Sejarah. Bandung: Satya Historika.

Abdullah, T (ed), (1997). Denyut Nadi Revolusi Indonesia. Jakarta: Gramedia.

Abdullah, T \& Lapian, A.B. (ed.). (2012). Indonesia Dalam Arus Sejarah 1-8. Jakarta: Ichtiar Baru van Hoeve

Anderson, B. (2006). Imagined Communities. Reflection on the Origin and Spread of Nationalism. London: Verso.

Ave, Jan B. (1989). “'Indonesia,' 'Insulinde' and 'Nusantara': Dotting the I's and Crossing the T", BKI, Vol.145, No. 2/3, 1989, pp.220-234

Benedict, P. K. (1942). "Thai, Kadai, and Indonesian: A New Alignment in Southeastern Asia”, American Anthropologist, Vol. 44, No.4, part 1, hlm. 576-601.

Departemen Penerangan R.I. (1964). Lahirnja Pantja-Sila. Djakarta: Pertjetakan Negara.

Dieter-Evers, H, (2016). "Nusantara: History of a Concept". JEMBRAS, Vol. 89 Part 1, No.310, hlm. 3-14.

Elson, $\mathrm{R}$, (2008). The Idea of Indonesia. Cambridge: Cambridge University Press.

Gellner, Er. (1983). Nations and Nationalism. Oxford: Basil Blackwell.

Hatta, M. (1953). Kumpulan Karangan. Djakarta: Penerbitan dan Balai Buku Indonesia.

Ingleson, J. (1993). Perhimpunan Indonesia dan Pergerakan Kebangsaan. Jakarta: Grafiti.

Kahin, G. Mc. (1955). Nationalism and Revolution in Indonesia. Ithaca: Cornell University Press.

Kartodirdjo, S. (2005). Sejak Indische Sampai Indonesia. Jakarta: Penerbit Buku Kompas.

Kayam, U. (1989). “Transformasi Budaya”, Pidato pengukuhan jabatan guru besar pada Fakultas Sastra UGM. Yogyakarta: Universitas Gadjah Mada.

Kumar, D.V. (2010). "Gellnerian Theory of Nation and Nationalism: A Critical Appraisal”, Sociological Bulletin, Vol. 59, No.3, hlm. 392-406.

Kuntowijoyo. (2000). "Indonesian Histroriography in Search of Identity”, Humaniora, Vol. 12, No. 1, hlm. 79-85. 
Lindsay, J \& L, Maya H.T. (ed.), (2011), Ahli Waris Budaya Dunia. Menjadi Indonesia 1950-1965. Jakarta-Denpasar: KITLV dan Pustaka Larasan.

Molewijk, G.C., (1987/1988). “Oude and nieuwe naamgeving van de Oostindische Archipel”, Jambatan, No. 5, pp. 5568.

Multatuli. (1991). Max Havelaar Atau Lelang Kopi Maskapai Dagang Belanda. Jakarta: Djambatan

Nagazumi, A. (1976). "Indonesia" dan "Orang-orang Indonesia”, S. Ichimura dan Koentjaraningrat, (ed), Indonesia Masalah dan Bunga Rampai. Jakarta: Gramedia, hlm. 1-25.

Nayono et al. (ed.). (1994). Karya Ki Hadjar Dewantara. Bagian II: Kebudayaan. Yogyakarta: Majelis Luhur Persatuan Tamansiswa.

Purwanto, B. (2001). "Memahami Kembali Nasionalisme Indonesia”, Jurnal Ilmu Sosial dan Ilmu Politik, Vol.4, No.3 March 2001, Yogyakarta: Fisipol UGM, hlm.243-264

Purwanto, B. (2006). Gagalnya Historiografi Indonesiasentris?! Yogyakarta: Ombak.

Purwanto, B. (2012). "Kesadaran Kebangsaan Indonesia dalam Perspektif Historis Penyerbukan Silang Antar Budaya”, Makalah Seminar. Yogyakarta: Yayasan Nabil \& Jurusan Sejarah Fakultas Ilmu Budaya UGM.
Purwanto, B. (2013). "Kearifan Lokal dan Masa Depan Kebangsaan Indonesia: Sebuah Pengantar Diskusi”, Makalah. Yogyakarta: Sekolah Pascasarjana Universitas Gadjah Mada.

Purwanto, B. (2017). "Ki Hadjar Dewantara, Berpolitik Dengan Akal Budi dan Hati Nurani”, Makalah Seminar, Jakarta: Museum Pergerakan Nasional.

Ricklefs, M.C. (2001). A History of Modern Indonesia since c. 1200. Third Edition. Basingstoke: Palgrave.

Rukmana, Aan \& Lembong, Eddie (ed), (2015). Penyerbukan Silang Antarbudaya: Membangun Manusia Indonesia, Jakarta: PT. Elex Media Kompatindo.

Smith, A.D. (1983). Theories of Nationalism. London: Duckworth.

Soedjatmoko. (2001). Kebudayaan Sosialis. Jakarta: Melibas.

Vickers. A. (2009). Peradaban Pesisir. Menuju Sejarah Budaya Asia Tenggara. Denpasar: Pustaka Larasan.

Vlekke, B.H.M. (2008). Nusantara. Sejarah Indonesia. Jakarta: KPG. 
Perspektif Historis Kesadaran Kebangsaan dan Kemerdekaan Indonesia Berdimensi Kebudayaan 